\title{
Supplier Evaluation Schemes in Case of Different Research Frameworks
}

\author{
PATó,G.,Sz.,B1 - KISS,F. ${ }^{2}$ \\ ${ }^{1}$ University of Pannonia, Department of Supply Chain Management, Veszprém, Egyetem str. 10., 8200, Tel.: \\ 8862 4645. email: patog@vnet.hu \\ 2University of Pannonia, Department of Supply Chain Management,Veszprém, Egyetem str. 10, 8200, Tel.: \\ 0036205335512 email: kfanni0125@gmail.com
}

Abstract. Performance evaluation is not only important in employer and employee relationships, but also in partnerships between a supply chain's members. In order to satisfy customers' needs according to the 7 Rights of logistics, all members of the given chain have to perform properly. To ensure the best performance, supplier evaluation can act as a starting point. Besides continous feedback, supplier evaluation plays an important role in performance development of suppliers. The aim of our research is to develop and introduce innovative supplier evaluation models, which include the advantages of traditional and electronic supplier evaluation forms. In addition to this, these models are visualised, making it easier to understand expectations and information. In this study, the aim is to present two different models the PaTeNt ${ }^{\odot-S E S C}$ (Pató Tetrahedrons of interNational Theory-Supplier Evaluation of Supply Chain) and the Douple Evaluation Platform, based on previous research.

\section{Introduction}

Supplier management is an important activity in most organizations, because the number of suppliers are on the rise in the market, customers would like to have more convenient quality and price with accurate transportation factors. Nowadays gamification is getting more widespread, which helps thinking in a 'playful' way and aims to cause more efficient work. In the spirit of gamification and on the basis of previous researches, two visualised supplier evaluation frameworks are developed. In this study, these two models the PaTeNt ${ }^{\odot-S E S C}$ (Pató Tetrahedrons of interNational Theory - Supplier Evaluation of Supply Chain) and the Douple Evaluation Platform are introduced in detail, through the example of local products and short supply chains. Due to visualisation, they foster the efficient processing, understanding and presentation of information.

\section{Gamification}

The appearance of gamification can be connected to digital media industry. Firstly it was mentioned in 2008, but it only became widespread in the second half of 2010, so it is a rather new definition. Due to it is relatively new appearance, the list of scientific literature on gamification is not so long. Gamification is the application of so-called conceptional game elements in non-game context. (Deterding et al.,2011) Non-game context means, that it is used in 
case of problem-solving, serious cases and business, not in order to entertain. Conceptional game elements are for example: teamwork, time pressure, rules, levels, feedback and 3D environment. (Reeves and Reed, 2010)

According to Zicherman (2011) gamification is the application of 'gameful' thinking and game mechanisms in order to solve a problem. Pacsi és Szabó (2017) defined gamification as the presentation of information in a gameful way in different territories of life towards customers. Game is an instinctive behaviour, which helps information processing and storage through experiences.

One of the main starting theory of gamification states that humans have a so-called 'gameful self' which is a basic element of behaviour. Not only in case of humans, but also of higher-order animals, gameful information forwarding is more efficient. (Pacsi és Szabó, 2017) The aim of gamification is to increase the motivation and commitment of employees through experiences. Actual work is present at the organiaztion as before, but some game mechanisms and technology appears in case of everyday operations. Due to the quite late appearance of gamification, it's theoretical and methodological background should be further developed and it is a question how it affects the motivation and behaviour of employees. (Warmelink et al., 2020)

Nowadays gamification appeared in the field of manufacturing and logistics as well. According to Warmelink et al. (2020) it is due to three major causes. Firstly, operational activities in the field of manufacturing and logistics are quite monotone and standardized. Secondly, technologies applied in these fields can be easily paralleld with the background and basic theories of gamification. Thirdly, automatized processes are not always cost-efficient, therefore human resources are still important. Gamification is a suitable opportunity which can be applied in order to enhance the performance of employees.

\section{Supplier evaluation - local products}

Organizations can be successful on the long-term, if they are capable of managing their suppliers efficiently. Some of the main activities of procurement are the selection and management of suppliers. In order to maintain a successful customer-supplier relationship, constant feedback and communication are inevitable, therefore supplier evaluation can act as a basis. Supplier evaluation is a type of performance evaluation between partners, occuring after completion. (Pató-Kopácsi-Kreiner,2016, p.253) According to Fehr and Rocha (2018) the main elements of an economically successful and mutually beneficial relationship are continous information sharing and trust, which enhances the application of supplier evaluation. Convenient communication, engagement and proficiency are must-have characteristics in case of suppliers. (Jin-Vidyaranya, 2016) The main aim of supplier evaluation is selecting the best supplier possible, developing the supplier's performance and controlling the relationships with suppliers. (Vörösmarty-Tátrai, 2010) There are several different methods for evaluating suppliers both in scientific literature and in practice as well. Szegedi-Prezenszki (2005) differentiate three distinct supplier evaluation methods. In case of the so-called simple categorical method, the buying department determines the most important factors to be evaluated. In general, 3-7 value categories are used in practice in order to maintain manageability. The main advantages of the 
model are: low costs and simplicity. On the other hand, categories should be regularly supervised, because ther is no numerical data. The cost-based supplier performance evaluation examines the ratio of prime costs. Complex evaluation procedures contains several methods, the common characteristics of these models is the use of numerical data. The determination of evaluation factors representing the organizational profile and expectations is of high importance in all methods. According to a quite recent research the most important evaluation factors are: supplier certification, quality, facilities, continous improvement, physical distribution and relationships. (Hwang et al., 2016)

In this study, the two supplier evaluation models are presented through local products' short supply chains. The definition of local products on the basis of Hungarian 123/2009 FVM regulation is: products that are locally sourced from conventional resources and locally produced with non-industrial technology but with a technology characteristic to a region, manufactured by a micro- or small company. Short supply chains are a type of supply chains in which only a few members (there is no or only a few intermediaries between manufacturers and final customers) are involved. Members are engaged towards cooperation, and the development of local economy is of high importance to all. (Kujáni, 2015) Short supply chains can often be identified in the marketing of local products, which can be significantly supported by the use of local money. (Juhász -Varga, 2018). At the same time, local products and short supply chains playing an increasingly important role in the economy, can also help to stimulate the labor market and encourage young people staying in the countryside (Dajnoki et al., 2018) through direct communication and the same set of values. (Szabó-Szentgróti et al., 2019)

\section{The introduction of Double Evaluation Platform}

The Double Evaluation Platform is a visualised supplier evaluation framework, which is advised to be applicated in short supply chains. Based on research results, this model involves both the aspects of central organization and customers. A supplier (local producer) is in the centre of the model, who is evaluated from two sides. The left side of the model is equal to a formal supplier evaluation where the central organization (e.g. retailer, service provider, intermediary) evaluates the supplier. Opposite to that, the evaluation of consumers can be read on the right side. The model has an outstanding advantage for the supplier because two evaluations can be seen in one common platform. Therefore suppliers receive a general view about their strenghs and weaknesses, providing the opportunity to enhance their performance. The method behind the model is based on the so-called simple categorical method. The central organization defines those most important evaluation factors (e.g. quality, price, delivery time, flexibility) based on which supplier evaluation takes place. Besides that, the accurate definition and number of evaluation categories are also required. On Figure 1 a sample of the Double Evaluation Platform can be seen, where the 1 . evaluation category means weak, and the 5. evaluation category equals outstanding performance. Evaluation factors and categories can be formed by the organization based on their profile. Chosen evaluation categories are marked by X in every evaluation factor. The central organization can compare its evaluation with the consumers' evaluation (which can be collected via online or offline methods by the central organization) in case of every evaluation factors. The final aim of central organisation and suppliers is to satisfy consumers' needs the 
highest level possible, therefore consumers' evaluation is just as important as supplier evaluation.

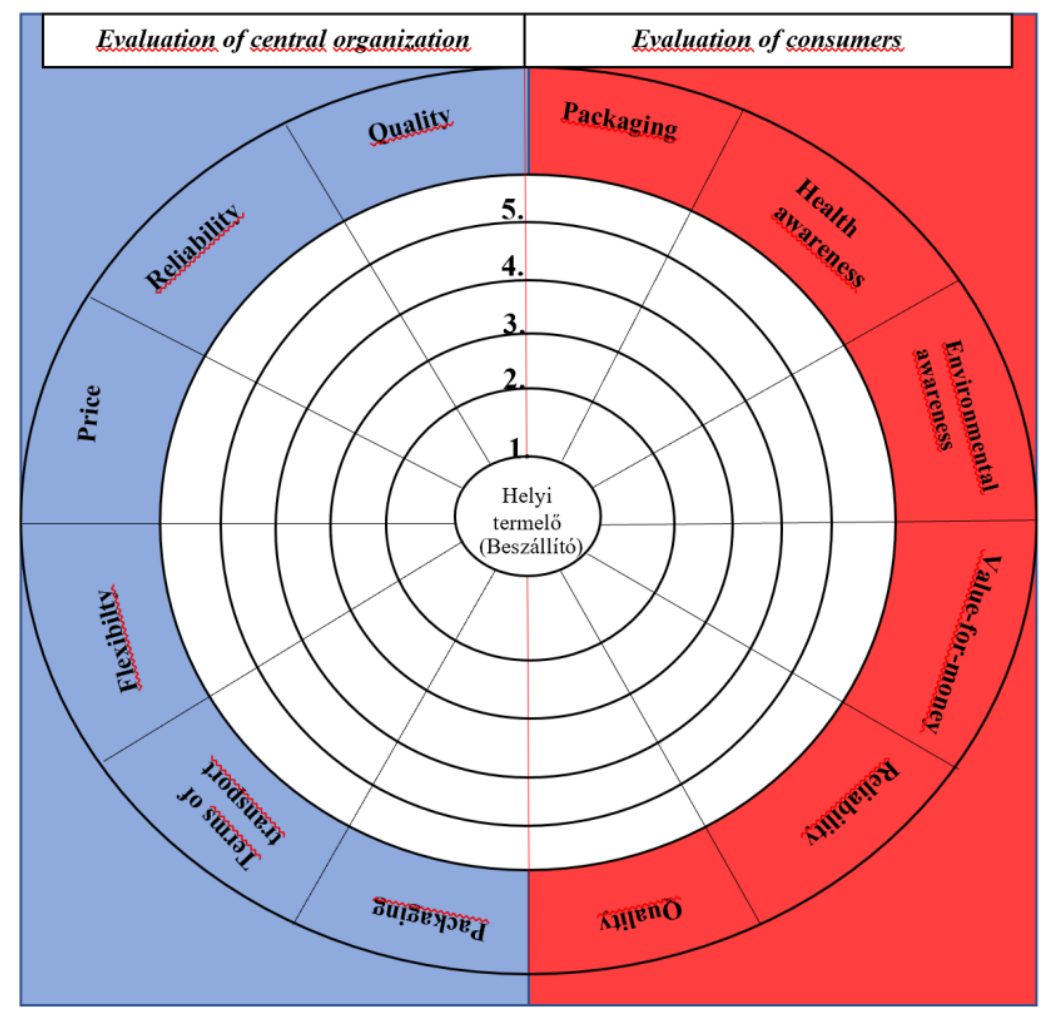

Figure 1: Double Evaluation Platform (Own construction)

\section{Introduction of $\mathrm{PaTeNt}{ }^{\complement}$ model}

Nowadays the presentation of information by spatial and visualised models are on the rise. The PaTeNt ${ }^{\complement}$ model is a scientific research tool, which contains five tetrahedrons. The aim of this model is to make the presentation and understanding of information easier due to visualisation. One of the main advantages of the model is that, it can be 'hold in hand', helping to identify and understand the connections between factors. Connecting more tetrahedrons together enables to reveal cause-and-effect relatedness. The PaTeNt ${ }^{\circledR}$ model is under the issue of design (nbr. 90806 certificate of registration and case number: D0500121). The model can be applied in many fields of science, such as organizational processes, education and as a methodolgical tool in systematic thinking. Within these different fields, the model can be used in any themes. In this study, the model is presented through the PaTeNt ${ }^{\circledR}$ - SESC (Pató Tetrahedrons of interNational Theory - Supplier Evaluation of Supply Chain) model, specialised for the short supply chains of local products. 


\subsection{Introduction of the model's five tetrahedrons}

The tetrahedrons represent different factors, which are separeted but there is important interaction between them. Thanks to the model, these factors can be linked and correlation between them can be easily presented. Three of the PaTeNt ${ }^{\odot}$-SESC model's tetrahedrons represent the most important members of short supply chains: suppliers, customers and service providers/integrator. The fourth tetrahedron is the local product and it's dimensions, which stream along the short supply chain. Finally, the fifth tetrahedron presents the marketingorientation, which is in symbiosis with the whole supply chain.
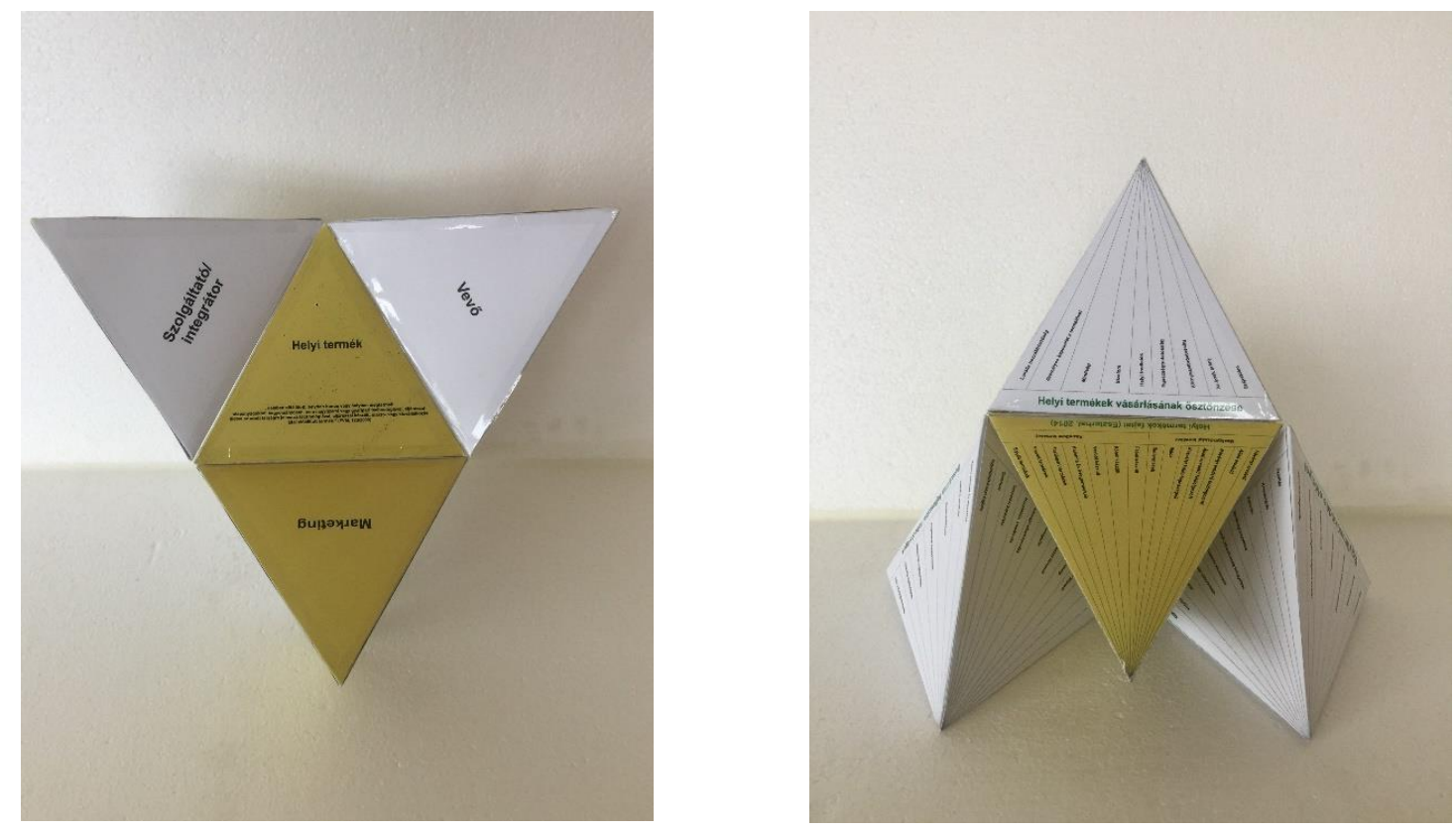

Figure 2: The PaTeNt ${ }^{\odot}$ - SESC (Pató Tetrahedrons of interNational Theory - Supplier Evaluation of Supply Chain) model (Source: Own pictures)

The five tetrahedrons contain the following factors and information:

- The supplier tetrahedron is made up of the supplier qualification (Bailey-Farmer, 1994) side, the supplier evaluation side and the supplier's potential opportunities for performance development.

- The service provider/integrator tetrahedron contains the activities carried out, the advantages of cooperation and trust sides.

- The customer tetrahedron is build up from the elements of 4C, (Lauterborn, 1990) the elements of logistical 9R, (Szegedi, 2008) and the opportunities to enhance purchasing local products.

- The local product tetrahedron contains the types of local products (Eszterhai, 2014), the characteristics of these products and the potential sales channels for local producers.

- The marketing tetrahedron includes the elements of 4P (McCarthy, 1960), the factors of marketing-logistics (Lambert-Stock, 1993) and promotion policy (Bauer et al, 2014).

The model enables the determination of two central tetrahedrons. Central tetrahedrons are the most important elements of the given theme and the other tetrahedrons are joint to these. In 
case of the PaTeNt ${ }^{\odot}$-SESC model two central elements are defined, the local product and the marketing tetrahedrons. These two central elements are in a direct relationship with all the other tetrahedrons and their factors.

With the help of the PaTeNt ${ }^{\odot}$-SESC model and the opportunities of gamification, the logical connections and cause-and-effect relationships can be easily presented. The network of tetrahedrons can visualise the levels and relationships between factors. In the PaTeNt ${ }^{\odot}-\mathrm{SESC}$ model sides are located on the tetrahedrons based on logical connections, helping to symbolize the cause-and-effect relationships. Several logical connections can be identified in the PaTeNt ${ }^{\odot}$ SESC model. It can be noted that, sales policy depends on the characteristics of local products, the elements of $4 \mathrm{P}$ are related to $4 \mathrm{C}$, sales channels linked tot he members of the supply chains and the factors of supplier evaluation depends on the characteristics of local products.

With the spatial formation of the tetrahedrons, specialised figures can be created. Pairing different edges of different tetrahedrons, more and more relationships can be presented. Due to movability, the arrangement of the tetrahedrons' sides are of high importance. In the PaTeNt ${ }^{\odot}-$ SESC model the connection between the central elements and the other three tetrahedrons can be seen with the help of movability. Connecting the five tetrahedrons results in a network, which can be further developed.

\subsection{Forms of dispersion}

Due to the special spatial shape of the model, it is possible to visualise horizontal and vertical dispersion. If the contents of the tetrahedrons are placed above each other, vertical dispersion can be seen. On the other hand, if the tetrahedrons are placed next to each other, it results in horizontal dispersion. In the PaTeNt ${ }^{\odot}$-SESC model vertical dispersion can be identified in case of local products' characteristics in short supply chains and between the elements of marketing. With the help of horizontal dispersion, the main members of short supply chains can be noticed.

In order to support visualisation, it is highly recommended to apply different colours on the model. Central elements can be marked by diverse and heightened colours emphasising their important role in the model. The visualised PaTeNt ${ }^{\odot}$-SESC model enables the understanding of relationships between the members in local products' short supply chains.

\section{Summary}

With the spread of gamification, the role of 3D and visualised models are rising continously. There is a growing need in case of organizational managers, employees and customers (X, Y and $\mathrm{Z}$ generation) to support the identification, understanding and flow of information, enabling easier and more efficient information processing. The two presented supplier evaluation frameworks, the Double Evaluation Platform and the PaTeNt ${ }^{\odot}$ - SESC (Pató Tetrahedrons of interNational Theory - Supplier Evaluation of Supply Chain) model raise attention towards fields, relationships and factors to be developed. With the help of these tools and on the basis of gamification, the understanding of correlating factors are supported by visualisation. These supplier evaluation frameworks represent local products' short supply chains, highlighting main 
relatedness and relationships between members. The 'gameful' application of these models support proactivity, development and collaboration between a supply chain's members.

\section{References}

[1] Bailey, P. - Farmer, D. (1994): Beszerzés, Stratégiai menedzsment, Műszaki Könyvkiadó

[2] Bauer, A. - Berács J. - Kenesei Zs. (2014): Marketing alapismeretek, Akadémiai Kiadó, Budapest

[3] Dajnoki K. - Szabados Gy. - Kulcsár G. - Bácsné Bába É. (2018): „Visszatérni vidékre” - A vidéki élet kvantitatív és kvalitatív megközelítésben. International Journal of Engineering and Management Sciences (IJEMS) Vol. 3. (2018). No. 5 DOI: 10.21791/IJEMS.2018.5.22.

[4] Deterding, S., Dixon, D., Khaled, R., \& Nacke, L. (2011, September). From game design elements to gamefulness: defining gamification. In Proceedings of the 15th International Academic MindTrek Conference: Envisioning Future Media Environments pp. 9-15

[5] Eszterhai, I. (2014): Helyi termék kézikönyv, Somogy Megyei Vállalkozói Központ Közalapítvány, Kaposvár, pp. 5-39.

[6] Fehr, A., F., C., L.,- Rocha, W. (2018): Open-book accounting and trust: influence on buyersupplier relationship, RAUSP Management Journal, Vol. 53, No.4., Sao Paulo, p.598

[7] Hwang, B., N.,- Chen, T., T.- Lin, J., T. (2016): 3PL selection criteria in integrated circuit manufacturing industry in Taiwan, Supply Chain Management: An International Journal, Vol.21, No.1, pp.103-124

[8] Juhász Z. - Varga I. (2018): A helyi pénz bevezetésnek fóbb tapasztalatai Magyarországon. Vezetéstudomány 49:3 pp.19-27.

[9] Kujáni, K. - Szabadkai, A. (2015): A helyi élelmiszerrendszer fejlesztési lehetôségei a Zala Termálvölgye egyesület térségében, Zala Termálvölgye Egyesület, Zalaszentgrót, IHF/77/2/2015, p.11

[10] Lambert, M., D. - Stock, J. R. (1993): Strategic Logistics Management, McGraw-Hill/Irwin

[11] Lauterborn, B. (1990): New marketing litany: Four Ps Passé: C-words take over, Advertising Age 61 (41) p.26

[12] Jin, S. - Vidyaranya, B., G. (2016): Supplier selection in small- and medium-sized firms, American Journal of Business, 31(4), p. 169

[13] McCarthy, E., J. (1960): Basic Marketing: A managerial approach, Richard D. Irwin Inc., Homewood

[14] Pacsi, D.- Szabó, Z. (2017): A gamifikáció fejlódése és a magyar gamifikációs trend alakulása, Studia Mundi - Economica, Vol.4 No. 1 pp. 57-68

[15] Pató, G. Sz. B.,-Kopácsi, E.-Kreiner, B. (2016): A beszállító értékelés vizsgálata SWOT analízis segítségével, Vállalkozásfejlesztés a XXI. században VI. tanulmánykötet, Óbudai Egyetem, Keleti Károly Gazdasági Kar, p.253.

[16] Pató Gáborné Szűcs Beáta - Pató Gábor - Dr. Kovács Zoltán (2006): Öt tetraéderből álló tudományos segédeszköz - kutatási modell, in. Szabadalmi Közlöny és Védjegyértesítő III. évfolyam 3. szám, D25 - D0500121 pp. D25

[17] Reeves, B. \& Read, J. L. (2010). Ten Ingredients of Great Games, Apr 10 
[18] Szegedi, Z. (2008): Logisztika Menedzsment, Kossuth Kiadó, Budapest

[19] Szegedi, Z. - Prezenszki, J. (2005): Logisztika menedzsment, Kossuth Kiadó, Budapest pp.92-95

[20] Vörösmarty, Gy. - Tátrai, T. (2010): Beszerzés, Stratégia, folyamatok, információ, Complex Kiadó Jogi és Üzleti Tartalomszolgáltató Kft., Budapest, pp.38

[21] Warmelink,H. - Koivisto, J. - Mayer, I. - Vesa, M.- Hamari, J. (2020) Gamification of production and logistics operations:Status quo and future directions, Journal of Business Research, 106 (2020) pp. 331-340

[22] Zicherman, G. (2011): A Long Engagement and a Shotgun Wedding: Why Engagement is the Power Metric of the Decade. Presentation, Gamification Summit, San Francisco, CA, 2011

[23] http://docplayer.hu/9324100-123-2009-ix-17-fvm-rendelet.html(letöltés dátuma:2019.10.18.) 